\section{PCR-based Genetic Analysis of DNA from Autopsied Prostate Tissue}

\author{
Jill A. Macoska, \\ Philip D. Benson, \\ Levent N. Turkeri, \\ Gabriel P. Haas, \\ and Wael Sakr ${ }^{2}$
}

Departments of ${ }^{1}$ Urology and

${ }^{2}$ Pathology, Wayne State University School of Medicine, Detroit, Michigan 48201
Prostate cancer is now the most commonly diagnosed cancer in males, with mortality approaching $25 \%{ }^{(1)}$ Allelic loss, or loss of heterozygosity ( $\mathrm{LOH})$, of chromosomal regions $8 \mathrm{p}, 10 \mathrm{q}$, and $16 \mathrm{q}$ are observed frequently in clinically evident prostate tumors, ${ }^{(2-4)}$ suggesting that they harbor tumor suppressor genes critical to the suppression of prostate tumor induction and progression. To elucidate the role of $\mathrm{LOH}$ for these and other chromosomal regions in prostate tumorigenesis, the frequency of these events must be examined in clinically latent, or "histologic" cancers, as well as in normal and premalignant glandular epithelial tissue from prostates without evidence of cancer. These tissues are difficult to obtain from surgical material but may be obtained from autopsy material. However, DNA isolated from autopsy-obtained tissue is difficult to analyze genetically because it is invariably degraded due to (1) fixation in formalin, which induces acid hydrolysis of DNA and protein-DNA cross-linking; and (2) autolysis, which may vary in severity depending on the interval between time of death and tissue procurement. In this paper we report a PCR-based technique that overcomes these obstacles by targeting nucleotide repeat polymorphic sequences to the chromosomal loci of interest in degraded DNA purified from formalin-fixed, paraffin-embedded autopsy tissue.

\section{MATERIALS AND METHODS}

Prostates obtained $\leqslant 12$ hr postmortem from men aged $<50$ years at time of death were formalin-fixed and embedded in paraffin following standard protocols. Histologic examination of serial sections showed no evidence of carcinoma. Portions of benign prostatic epithelial tissue were sectioned serially for molecular analysis into $5-\mu \mathrm{m}$ sections and applied to slides without coverslips. A median section was stained with hematoxylin/eosin (H/E) for histologic evaluation. Areas of benign glandular epithelium 3-5 $\mathrm{mm}$ in diameter were circled on the H/E-stained slide, which was then used as a template for excision of similar areas from adjacent nonstained sections. ${ }^{(4)}$ After deparaffinization of the nonstained slides in xylenes, the circumscribed tissue areas were scraped into $0.5-\mathrm{ml}$ tubes and digested in $75 \mu \mathrm{l}$ of $1 \times$ PCR buffer $[50 \mathrm{~mm} \mathrm{KCl}, 10 \mathrm{~mm}$ Tris- $\mathrm{HCl}$
(pH 8.3), $2.5 \mathrm{~mm} \mathrm{MgCl}_{2}$ ] supplemented with $0.1 \mathrm{mg} / \mathrm{ml}$ of proteinase $\mathrm{K}$. The samples were incubated for $12-16 \mathrm{hr}$ at $37^{\circ} \mathrm{C}$ with shaking, then for $20 \mathrm{~min}$ at $95^{\circ} \mathrm{C}$ to inactive the proteinase $K$. A PCR reaction mix comprising $1 \times$ PCR buffer; $200 \mu \mathrm{M}$ each dGTP, dATP, dTTP, and dCTP; 2.5 $\mu \mathrm{Ci}$ units of $\left[\alpha^{-32} \mathrm{P}\right] \mathrm{dCTP}$ (New England Nuclear $3000 \mathrm{Ci} / \mathrm{mmole}$ ); $1 \mu \mathrm{M}$ oligonucleotide primers; 0.5 units of Amplitaq (Perkin-Elmer Cetus); and sterile water to $25 \mu$ l per reaction was made up in $20 \times$ excess. Twenty microliters of the reaction mix was added to $5 \mu$ l of each DNA sample, each reaction was overlayed with 2 drops of mineral oil, and temperature cycling was initiated. The cycles consisted of $95^{\circ} \mathrm{C}$ for $5 \mathrm{~min}$ (to completely denature template) for 1 cycle; $95^{\circ} \mathrm{C}$ for $1 \mathrm{~min}, 55^{\circ} \mathrm{C}$ or $60^{\circ} \mathrm{C}$ for $1 \mathrm{~min}$ (primer-dependent), and $72^{\circ} \mathrm{C}$ for $1 \mathrm{~min}$ for 35 cycles; $72^{\circ} \mathrm{C}$ for $7 \mathrm{~min}$, and a $4^{\circ} \mathrm{C}$ soak to stop reactions. Upon completion of temperature cycling, $10 \mu \mathrm{l}$ of loading dye (10 $\mathrm{mm} \mathrm{NaOH}, 95 \%$ formamide, $0.05 \%$ bromphenol blue, $0.05 \%$ xylene cyanol) was added to each PCR reaction, and the mineral oil removed. Six microliters of each reaction plus dye sample was electrophoresed on $8 \%$ acrylamide/7 $M$ urea sequencing gels at $40 \mathrm{~W}(\sim 1500$ $\mathrm{V})$. A lane of each gel was reserved for coelectrophoresis of end-labeled DNA molecular mass marker (Hinfl digestion of pBR322). Upon completion of electrophoresis, gels were dried under vacuum and exposed to X-ray film at room tem. perature without screens.

\section{RESULTS AND DISCUSSION}

As shown in Figure 1, DNA prepared from seven autopsy prostate samples was amplified using primers specific to sequences containing nucleotide repeat polymorphisms on 10q11.2-qter (D10S91 locus, 6 alleles, 115-125 bp; Fig. 1A), ${ }^{(5)}$ 8p22 (LPL locus, 3 alleles of 123, 127, or 131 bp; Fig. 1B), ${ }^{(6)}$ 16q22.2-23.1 (D16S289 locus, 8 alleles, 156-172 bp; Fig. 1C), ${ }^{(7)}$, or 11p15 (D11S860 locus, 12 alleles, $154-196$ bp; Fig. 1D). ${ }^{(8)}$ Heterozygosity was evident by the appearance of two gel bands, one for each allele of the locus; homozygosity was evident by the appearance of one band. All seven specimens were heterozygous for the D10S91 locus (Fig. 1A). All but speciment 1 were heterozygous for the LPL locus (Fig. 1B). The significance, if any, of artifactual 


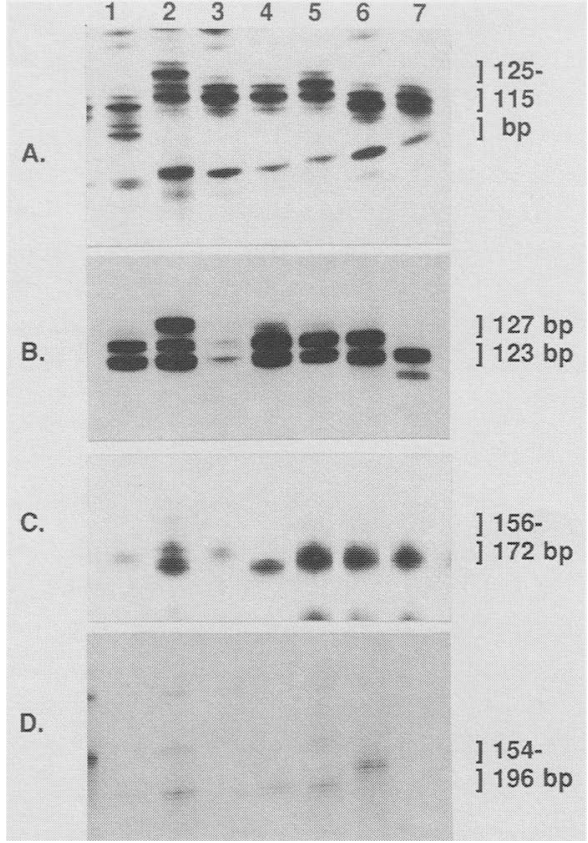

FIGURE 1 PCR analysis of DNA purified from autopsied prostated tissues. DNA isolation and PCR reactions were performed as described in Materials and Methods for tissue from seven autopsy prostates (lanes $1-7$ ). The reaction products were visualized by gel electrophoresis followed by autoradiography. The autoradiographs shown demonstrate amplified products of nucleotide repeat sequences of the D1010S91 locus $(A)$, LPL locus $(B)$, D165289 locus $(C)$, and D115860 locus $(D)$. Amplicon length (in bp), is indicated at right.

bands evident from specimens 2 and 7 is unknown. Homozygosity at the D16S289 locus was demonstrated by specimens 1,3 , and 4 ; the others were heterozygous, though resolution of both allelic bands for specimens 5-7 was incomplete. Heterozygosity at the D11S860 locus was evident for specimens 2 and 5; homozygosity was evident for specimens 4 and 6; and no reaction products were obtained for specimens 1 , 3 and 7 (Fig. 1C). As might be expected for benign tissue, none of the specimens heterozygous at these loci demonstrated partial or complete allelic loss.

These experiments demonstrate that genetic analysis of DNA prepared from autopsy tissue may be accomplished by using PCR techniques. In particular, effective amplification of sequences in DNA prepared from autopsy tissue is dependent on amplicon length, because sequences $<175 \mathrm{bp}$ in length (e.g., at the LPL, D10S91, and D16S289 loci) were amplified successfully, whereas se- quences $>175$ bp in length (e.g., at the D11S860 locus) were not. This finding is consistent with other experimental results (not shown) using the same specimens that demonstrated successful amplification of a 150-bp portion of the ZFY locus, but not of a larger, overlapping 327-bp sequence from the same locus. Because the 327-bp ZFY sequence, and other sequences $>175$ bp in length, are amplifiable in formalin-fixed, paraffinembedded surgical tissue ${ }^{(4)}$ but not in similar tissue obtained from autopsy, we conclude that increased DNA degradation in autopsy tissue permits the amplification of only relatively "short" sequences, that is, those $<327$ (and perhaps <175) bp in length. Attention to these criteria should enable genetic evaluation of benign tissue not associated with malignancies, putative premalignant, and early neoplastic lesions in the prostate and other tissues, thus, elucidating critical early genetic alterations in tumor progression.

\section{REFERENCES}

1. Boring, C.C., T.S. Squires, and T. Tong. 1991. Cancer statistics. CA: Cancer J. Clin. 41: $19-36$.

2. Collins, V.P., K. Kunimi, U. Bergerheim, and P. Eckman. 1991. Molecular genetics and human prostate carcinoma. Acta Oncol. 30: 181-185.

3. Carter, B.S., C.M. Ewing, W.S. Ward, B.F. Treiger, T.W. Aladers, J.A. Schalken, J.l. Epstein, and W.B. lsaacs. 1990. Allelic loss of chromosomes $16 \mathrm{q}$ and $10 \mathrm{q}$ in human prostate cancer. Proc. Natl. Acad. Sci. 87: 8751-8755.

4. Wolman, S.R., J.A. Macoska, M.A. Micale, and W. Sakr. 1992. An approach to definition of genetic alterations in prostate cancer. Diagn. Mol. Pathol. 1: 192-199.

5. Decker, R.A., J. Moore, B. Ponder, and J.L. Weber. 1992. Linkage mapping of human chromosome 10 microsatellite polymorphisms. Genomics 12: 604-606.

6. Zuliani, G. and H.H. Hobbs. 1990. Tetranucleotide repeat polymorphism in the LPL gene. Nucleic Acids Res. 18: 4858.

7. Shen, Y. Personal communication to Genome Data Base/OnLine Mendelian Inheritance in Man.

8. Reeve, A. Personal communication to Genome Data Base/OnLine Mendelian Inheritance in Man.

Received January 19, 1993; accepted in revised form February 2, 1993. 


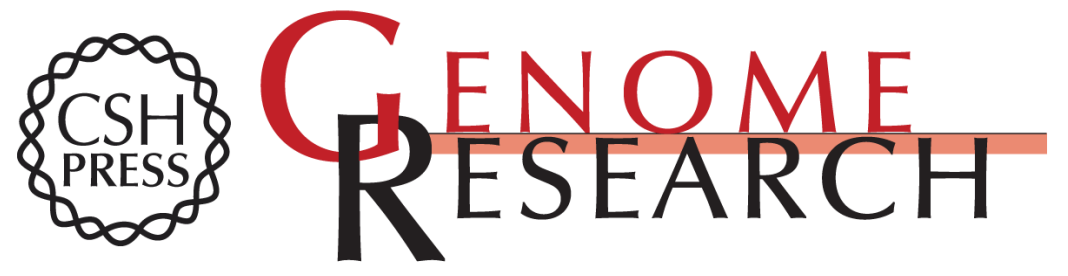

\section{PCR-based genetic analysis of DNA from autopsied prostate tissue.}

J A Macoska, P D Benson, L N Turkeri, et al.

Genome Res. 1993 2: 354-355

Access the most recent version at doi:10.1101/gr.2.4.354

$\begin{array}{ll}\text { References } & \begin{array}{l}\text { This article cites } 6 \text { articles, } 1 \text { of which can be accessed free at: } \\ \text { http://genome.cshlp.org/content/2/4/354.full.html\#ref-list-1 }\end{array}\end{array}$

License

Email Alerting Receive free email alerts when new articles cite this article - sign up in the box at the Service top right corner of the article or click here.

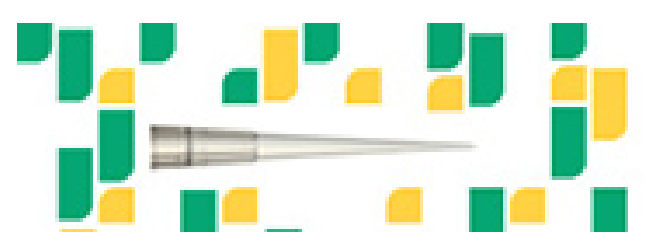

To subscribe to Genome Research go to: https://genome.cshlp.org/subscriptions 